ISSN 0258-7122 (Print), 2408-8293 (Online)

Bangladesh J. Agril. Res. 41(4): 759-772, December 2016

\title{
EFFECT OF NITROGEN AND PHOSPHORUS ON GROWTH AND SEED YIELD OF FRENCH BEAN
}

\author{
S. S. KAKON ${ }^{1}$, M. S. U. BHUIYA ${ }^{2}$, S. M. A. HOSSAIN ${ }^{2}$ \\ Q. NAHER ${ }^{3}$ AND MD. D. H. BHUIYAN ${ }^{4}$
}

\begin{abstract}
Field experiments were conducted during rabi (winter) seasons of 2010-11 and 2011-12 at the Bangladesh Agricultural Research Institute (BARI), Joydebpur, Gazipur to study the effects of nitrogen and phosphorus on growth, dry matter production and yield of French bean. A randomized complete block design was followed with 10 combinations of $\mathrm{N}(0,50,100,150$ and 200) and $\mathrm{P}(0,22,33$, 44 and 55) $\mathrm{kg} \mathrm{ha}^{-1}$ along with a blanket dose of control. All the treatments showed the maximum leaf area index (LAI) at 65 days after sowing (DAS). All the treatments showed the maximum total dry matter production, crop growth rate and net assimilation rate at harvest and at 55-65 DAS, respectively in both the years. LAI, dry matter production, CGR, NAR and seed yield significantly increased with the increase in nitrogen and phosphorus level upto $150 \mathrm{~kg} \mathrm{~N}$ and $44 \mathrm{P} \mathrm{kg} \mathrm{ha}^{-1}$, respectively. Similar trend was followed in maximum number of pods (9.45) and seed yield (1563.33 kg ha $\left.{ }^{-1}\right)$. The treatment comprises with 150 $\mathrm{kg} \mathrm{N}$ and $44 \mathrm{P} \mathrm{Kg} \mathrm{ha}^{-1}$ gave the highest seed yield which was 51.40 and $54.30 \%$ higher than control plots.
\end{abstract}

Keywords: French bean, growth, dry matter production, nitrogen, phosphorus and seed yield

\section{Introduction}

French bean (Phaseolus vulgaris L.) is a short duration high yielding grain legume crop and it can be used both as pulse and vegetable. The cultivation of French bean is gaining popularity in Bangladesh during the recent years mainly because of its export demand and increasing consumer preference. Hortex Foundation of Bangladesh already started to export French bean (BARI, 2001) as vegetable. Its dry seeds are used in preparations with fish, meat and other vegetables. Foliage of the crop may also provide hay, silage and green manures. After harvest, plants can be fed to cattle, sheep and horses. So there is a tremendous scope to improve its cultivation in our country. For proper growth and development of a crop nutrients elements are essential. Nitrogen is one of the key elements for growth and development of a crop plants (Tanaka et al.,1984). Nitrogen deficiency constraints leaf area expansion, enhances leaf senescence,

\footnotetext{
${ }^{1}$ Senior Scientific Officer, Agronomy Division, ${ }^{3}$ Senior Scientific Officer, On farm Research Division, Bangladesh Agricultural Research Institute (BARI), Gazipur-1701, ${ }^{2}$ Professor, Bangladesh Agricultural University (BAU), Mymensingh-2200 and ${ }^{4}$ District Monitoring Officer, Narsingdi, Bangladesh.
} 
inhibits photosynthetic rate in most of the crops and consequently reduces the crop productivity (Machler et al., 1988 and Wolfe et al.,1988).

The capacity for nitrogen fixation was reported to be ranging between 64-121 kg ha $^{-1}$ (Rennie and Kemp, 1983). Nitrogen is critically deficient and the most limiting element in soils of Bangladesh (Hoque, 1993). Reddy et al. (2010) also reported that increased nitrogen levels from 75 to $150 \mathrm{~kg} \mathrm{ha}^{-1}$ improved the yield attributes and seed yield $\left(520 \mathrm{~kg} \mathrm{ha}^{-1}\right)$ over $125,100,75 \mathrm{~kg} \mathrm{~N}^{-1}$, respectively. French bean also responds well to phosphorus application ( Siddiqui, 2010). Phosphorus deficiency triggers many morphological, biochemical and molecular changes in plants. It affects on nodulation, nitrogen fixation and plant growth in legume crops. In view of this, an experiment was initiated to find out the optimum level of nitrogen and phosphorus fertilizer for exploiting the yield potential of French bean.

\section{Materials and Method}

The experiment was conducted on Agronomy research field of Bangladesh Agricultural Research Institute (BARI), Joydebpur under Gazipur district of Bangladesh during the period from November to March in 2010-11 and 2011-12. The experiment site was located Chhiata Series under Agro-Ecological Zone-28 (AEZ-28) latitude $23^{\circ} 59 / \mathrm{N}$ and longitude $90^{\circ} 24 / \mathrm{E}$. The rainfall during the experimental period was $42.0 \mathrm{~mm}$ in first year and $189 \mathrm{~mm}$ in second year, respectively. Before opening the land, the soil samples were taken from the spots of the experimental area and analyzed from the Soil Science Division, BARI. The soil analysis showed that the soil of the experimental field was loam in texture and low in organic matter $(1.27 \%)$. The soil was acidic in nature with $\mathrm{pH}(6.1)$ and contained very low amount of total nitrogen $(0.067 \%)$, phosphorus $(9.6 \%)$, sulphur $(12 \%)$, zinc $(2 \mathrm{meq} / 100 \mathrm{~g})$ and medium amount of potassium $(0.18$ meq/100 g). The experiment was laid out in a randomized complete block design (RCBD) with three replications. There were ten treatment combinations such as $\mathrm{N}_{0} \mathrm{P}_{0}, \mathrm{~N}_{0} \mathrm{P}_{44}, \mathrm{~N}_{50} \mathrm{P}_{44}, \mathrm{~N}_{100} \mathrm{P}_{44}, \mathrm{~N}_{150} \mathrm{P}_{44}, \mathrm{~N}_{200} \mathrm{P}_{44}, \mathrm{~N}_{150} \mathrm{P}_{0}, \mathrm{~N}_{150} \mathrm{P}_{22}, \mathrm{~N}_{150} \mathrm{P}_{33}$ and $\mathrm{N}_{150} \mathrm{P}_{55}$. The sources of $\mathrm{N}$ was urea and that of $\mathrm{P}$ was triple super phosphate. Each plot was uniformly fertilized with @ 60-20-2 K-S-Zn through muriate of potash, gypsum and zinc sulphate (Mozumder et al., 2003) and the total amount of TSP and 50\% of urea were mixed with the soil during final land preparation and the rest urea was top dressed at 35 days after sowing (DAS). The seeds of French bean var. BARI Jharsheem-1 were sown in the field on 25 November, 2010 and 24 November, 2011. Seeds were treated with vitavax and sown continuously in $30 \mathrm{~cm}$ apart rows and plant to plant distance $15 \mathrm{~cm}$. Weeding was done with hand at 25 and 40 DAS. For uniform germination, a light irrigation was given by sprinkler method after sowing of seeds. Three irrigations were given at 25, 40 and 60 DAS. The crops were attacked by cutworm (Agrotis ipsilon) and hairy caterpillar (Spilarctia obliqua) at early growth (vegetative) stage. The cutworm was controlled through 
hand picking and hairy caterpillar by spraying Perfecthion 40EC @ $2.0 \mathrm{ml} \mathrm{L}^{-1}$ of water at an interval of 7-10 days for two to three times. Five plants from each replication were randomly tagged for daily count of opened flowers. Flower counts began from the date of opening of the first flower and were continued daily until flowering ceased. Total flower production and mature pods were counted at harvest. Data on leaf area and dry matter accumulation were recorded every 15 day intervals starting from 20 to 80 DAS and dried at $70{ }^{\circ} \mathrm{C}$ for 72 hours to a constant weight and dry weight was taken. Different growth parameters such as LAI, CGR NAR also measured using methods as suggested by Gardner et al. (1985). The yield component data was collected from 10 randomly selected plants prior to harvest from each plot. At harvest, the yield data was recorded, analyzed statistically and means were separated using DMRT and $r$ value were done following the Microsoft EXCEL 2003.

\section{Results and Discussion}

\section{Effect of nitrogen and phosphorus on growth parameters}

Leaf area index (LAI) of French bean was significantly influenced by different levels of nitrogen in both the years. Plants treated with $150 \mathrm{~kg} \mathrm{~N} \mathrm{ha}^{-1}$ produced the highest LAI throughout the whole growth period which was identical to 200 $\mathrm{kg} \mathrm{N} \mathrm{ha}{ }^{-1}$ and without $\mathrm{N}$ gave the lowest LAI in both the years. The LAI value increased consistently up to 65 days after sowing (DAS) and thereafter it decreased due to leaf senescence (Fig 1 and 2). Different levels of applied phosphorus significantly influenced the leaf area index in both the years (Fig. 3 and 4). Application of P levels also significantly affected the LAI from 20 DAS to 80 DAS. LAI increased up to $44 \mathrm{~kg} \mathrm{P} \mathrm{ha}^{-1}$ and then decreased. Maximum LAI ( 2.26 in 2010-11 and 2.29 in 2011-12) was recorded at 65 DAS from the plants treated with $44 \mathrm{~kg} \mathrm{P} \mathrm{ha}^{-1}$ and the minimum LAI was in control plot.

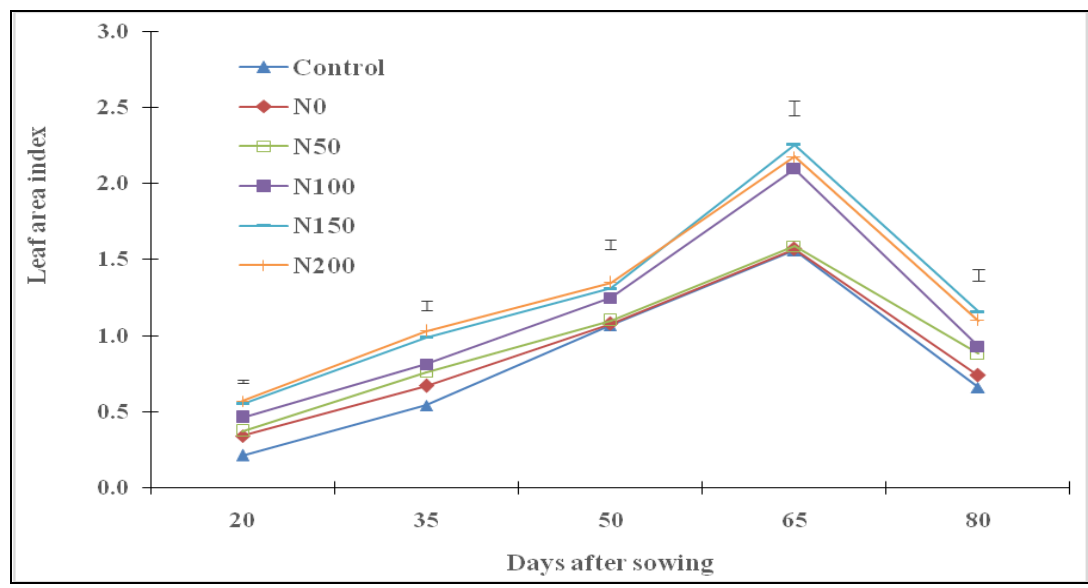

Fig. 1. Leaf area index of French bean as influenced by nitrogen levels in Rabi season of 2010-11. 


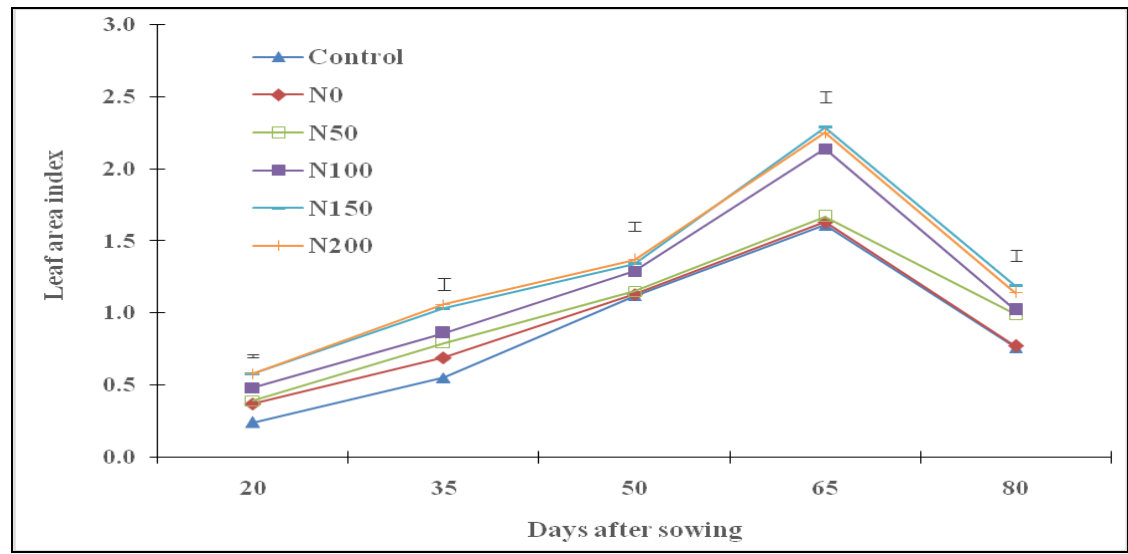

Fig. 2. Leaf area index of French bean as influenced by nitrogen levels in Rabi season of 2011-12.

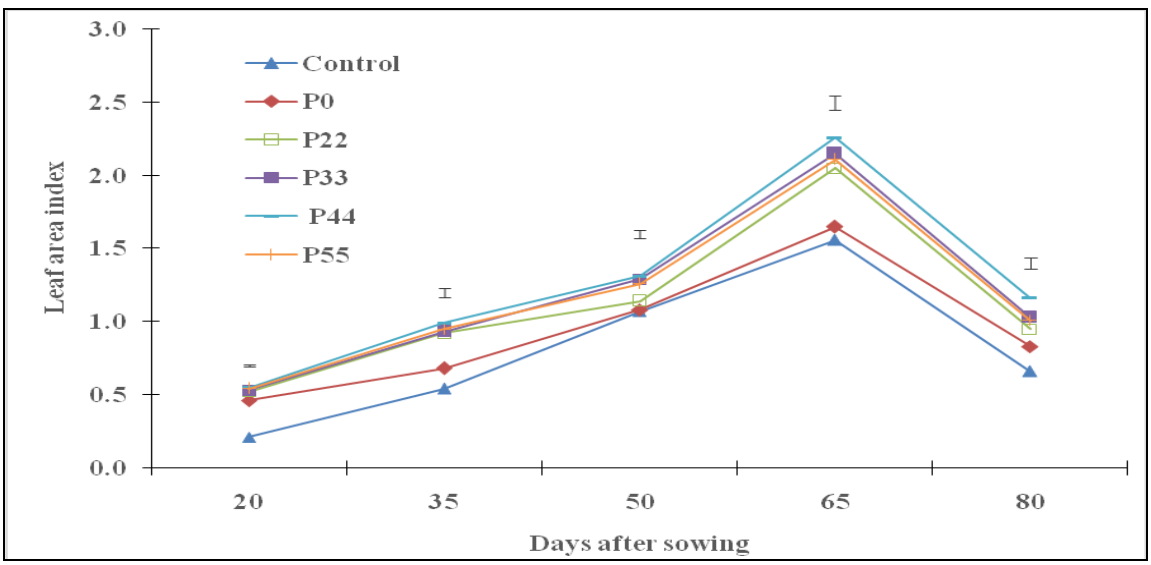

Fig. 3. Leaf area index of French bean as influenced by phosphorus levels in Rabi season of 2010-11.

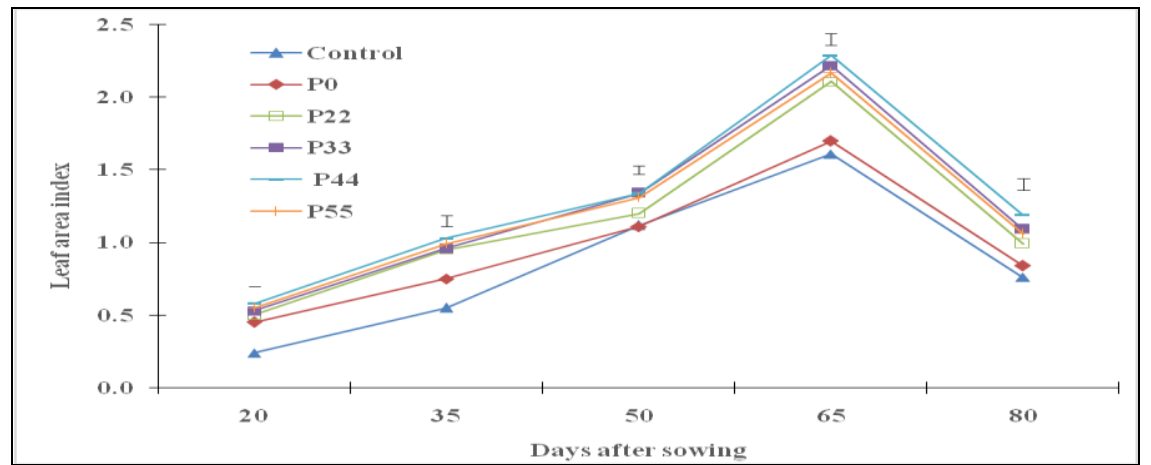

Fig. 4. Leaf area index of French bean as influenced by phosphorus levels in Rabi season of 2011-12. 


\section{Dry matter production}

Total dry matter (TDM) production of French bean at different growth stages was significantly influenced by nitrogen (Fig. 5 and 6) where significantly higher dry matter was obtained with added $\mathrm{N}$ at all the growth stages. Among the nitrogen treatment, 150 to $200 \mathrm{~kg} \mathrm{ha}^{-1}$ showed the similar dry matter production in both the years whereas without nitrogen $\left(\mathrm{N}_{0}\right)$ produced the lowest one. A slow growth was observed until 20 DAS followed by a rapid growth till 65 DAS, thereafter the growth rate decreased but did not flatten off. Similar trend was also observed in French bean (Dhanjal et. al., 2003 ) and by Ferdous et. al. (2004) in podded pea. Total dry matter production of French bean significantly influenced by the phosphorus fertilizer (Fig. 7 and 8) and total dry mass increased all over the growth stages. Consistently higher TDM was observed in plants treated with $\mathrm{N}_{150}$ $\mathrm{P}_{44} \mathrm{~kg} \mathrm{ha}^{-1}$ at all the growth stages in both the years. Further increase in $\mathrm{P}$ rate tended to depress DM accumulation but the plants grown without added $\mathrm{P}$ produced the lower dry matter.

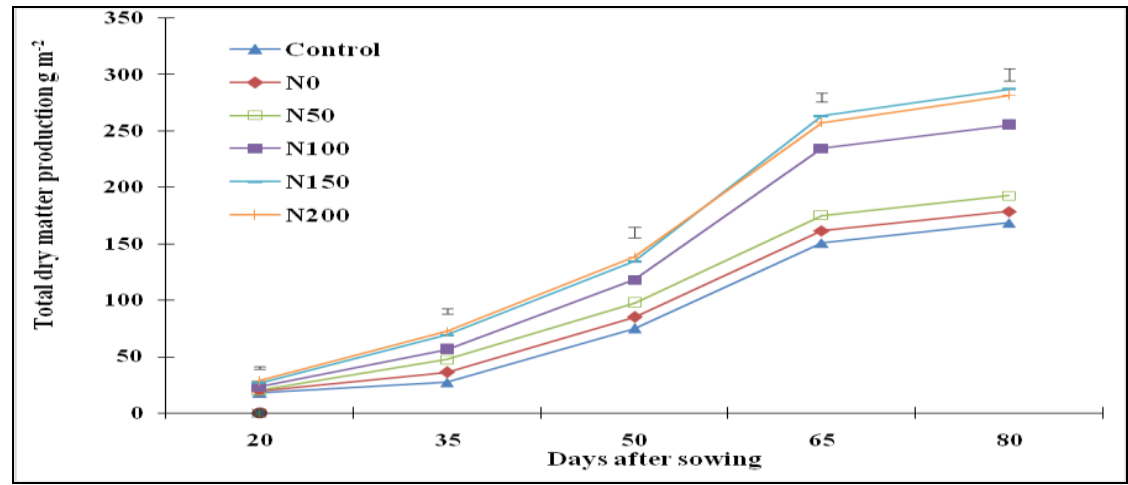

Fig. 5. Total dry matter production of French bean as influenced by nitrogen levels in Rabi season of 2010-11.

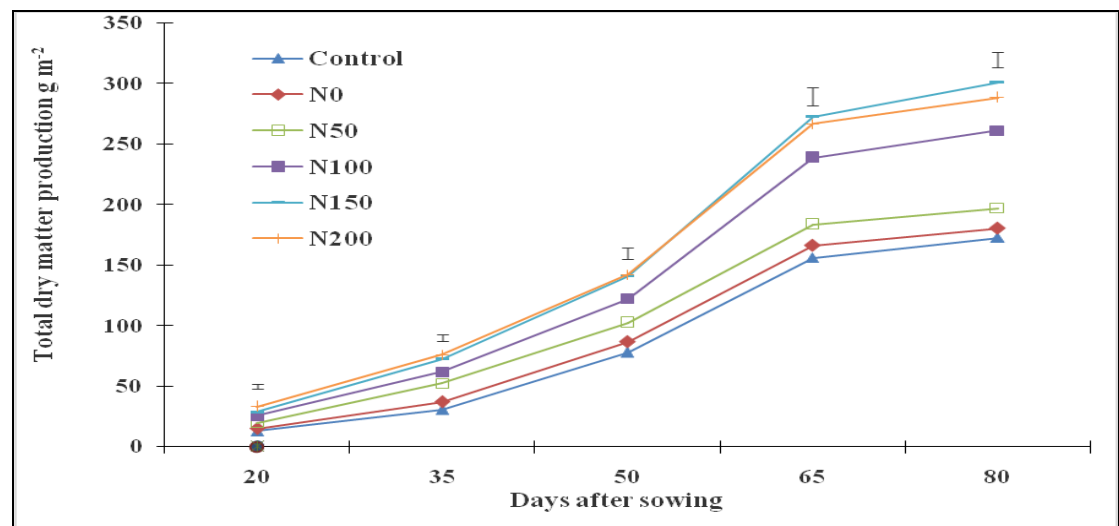

Fig. 6. Total dry matter production of French bean as influenced by nitrogen levels in Rabi season of 2011-12. 


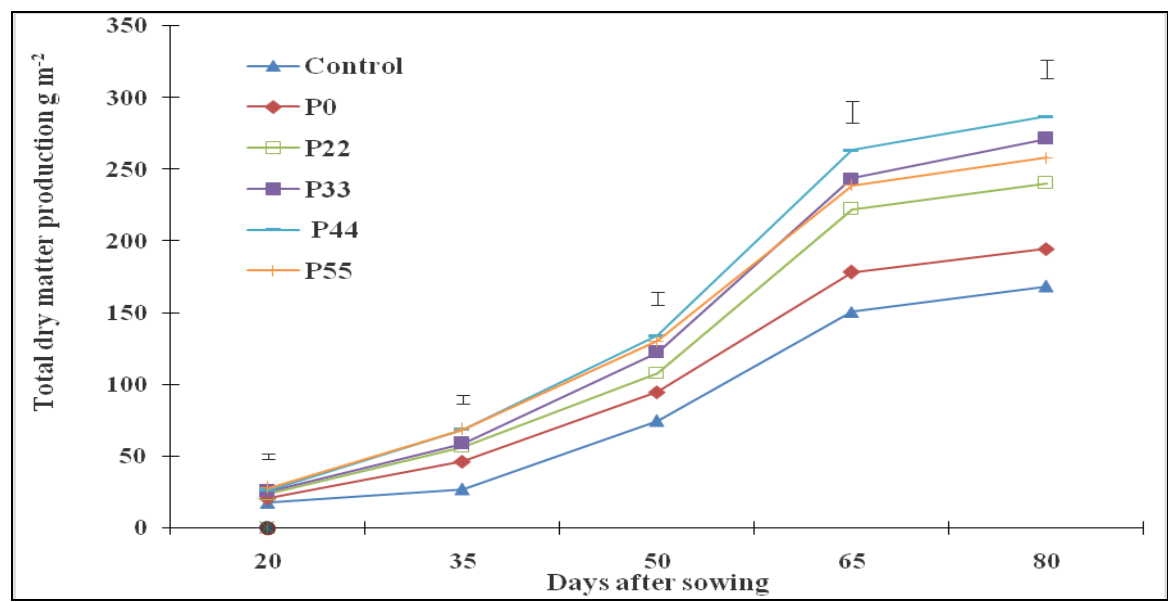

Fig. 7. Total dry matter production of French bean as influenced by phosphorus levels in Rabi season of 2010-11.

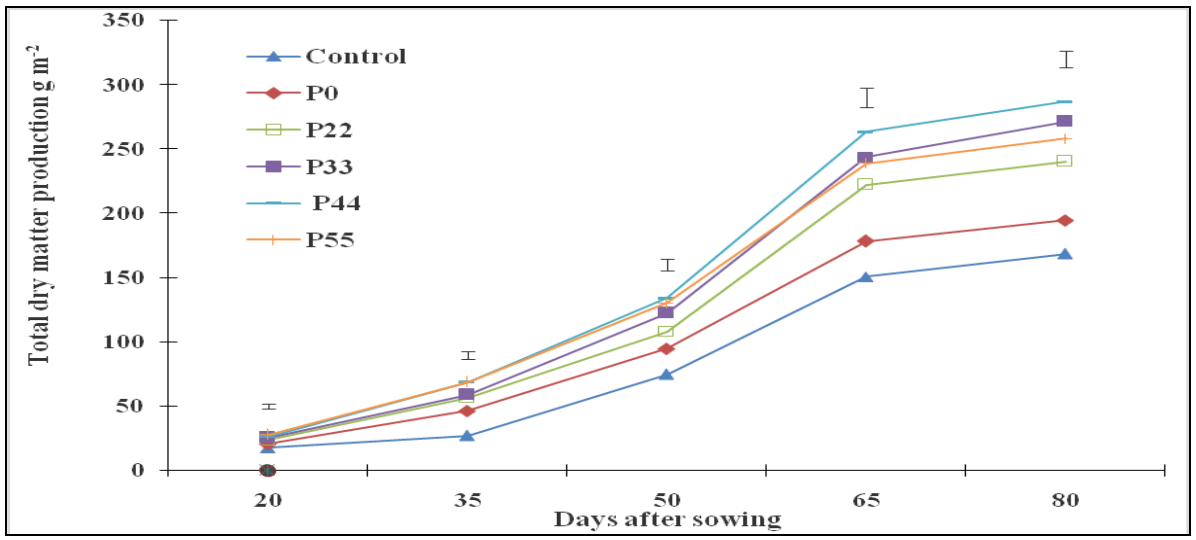

Fig. 8. Total dry matter production of French bean as influenced by phosphorus levels in Rabi season of 2011-12.

\section{Crop growth rate}

The crop growth rate in French bean was influenced by the nitrogen fertilizer treatments (Fig. 9 and 10) and increased progressively with time reaching the peak at 50-65 DAS and thereafter decreased gradually till maturity because of cessation of vegetative growth, senescence of leaves. Among the treatments, 150 $\mathrm{kg} \mathrm{N} \mathrm{ha}{ }^{-1}$ registered a maximum crop growth rate while plants without nitrogen and phosphorus $\left(\mathrm{N}_{0} \mathrm{P}_{0}\right)$ gave the lowest crop growth rate (CGR) in both the years. At 50-65 DAS, $150 \mathrm{~kg} \mathrm{~N}^{-1}$ produced the maximum $\left(8.62 \mathrm{~g} \mathrm{~m}^{-2} \mathrm{~d}^{-1}\right.$ in $2010-11$ and $8.78 \mathrm{~g} \mathrm{~m}^{-2} \mathrm{~d}^{-1}$ in 2011-12, respectively) crop growth rate (CGR) which was identical to $200 \mathrm{~kg} \mathrm{~N} \mathrm{ha}^{-1}$. This result was in agreement with Ferdous et al. (2004) in edible podded pea and Siddiqui (2010) in French bean. Different levels 
of applied phosphorus significantly influenced the crop growth rate (CGR) of French bean throughout the growth period (Fig. 11 and 12) in both the years. Plants treated with $44 \mathrm{~kg} \mathrm{P} \mathrm{ha}^{-1}$ had the highest crop growth rate (CGR) at 50-65 DAS and it was $35.38 \%$ and $37.13 \%$ higher over the $\mathrm{P}$ control.

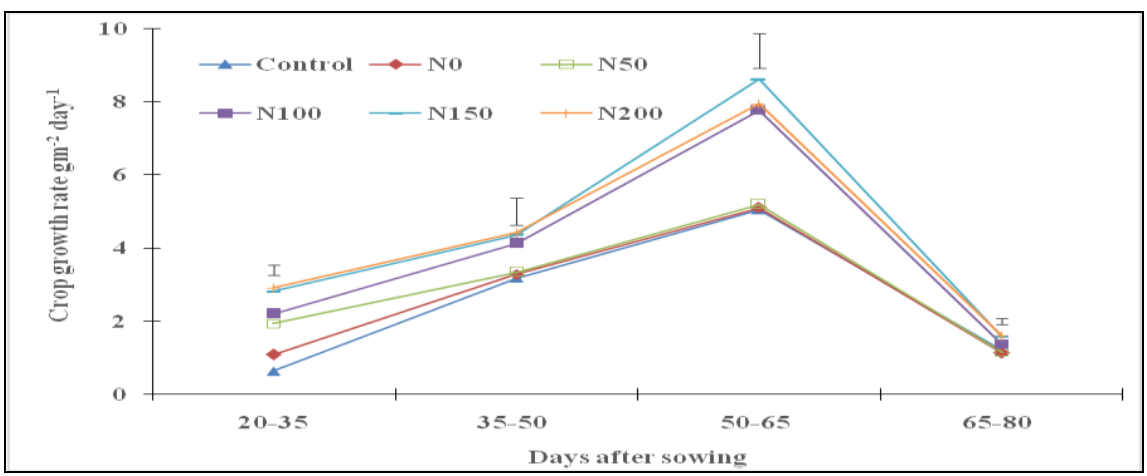

Fig. 9. Crop growth rate of French bean as influenced by nitrogen levels in Rabi season of 2010-11.

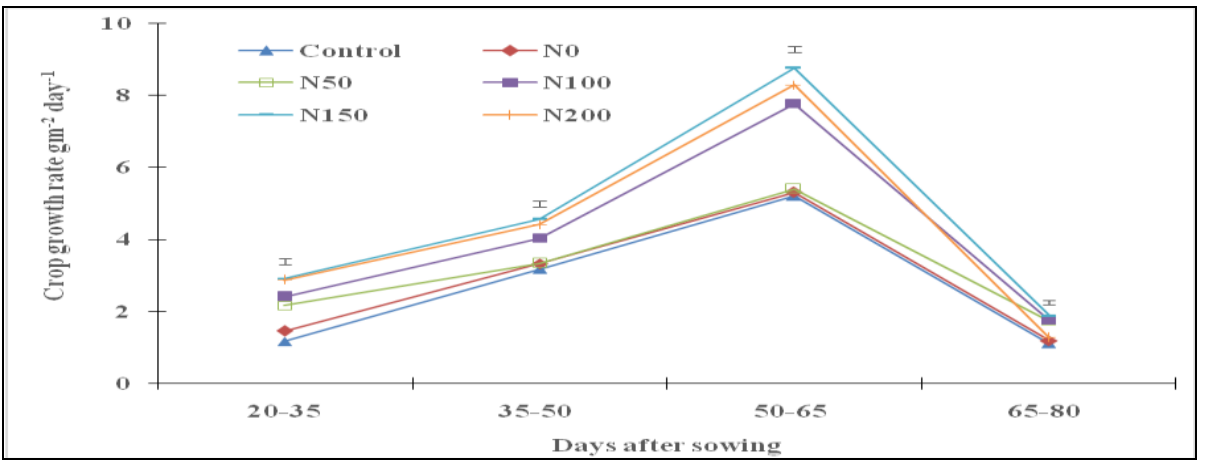

Fig. 10. Crop growth rate of French bean as influenced by nitrogen levels in Rabi season of 2011-12.

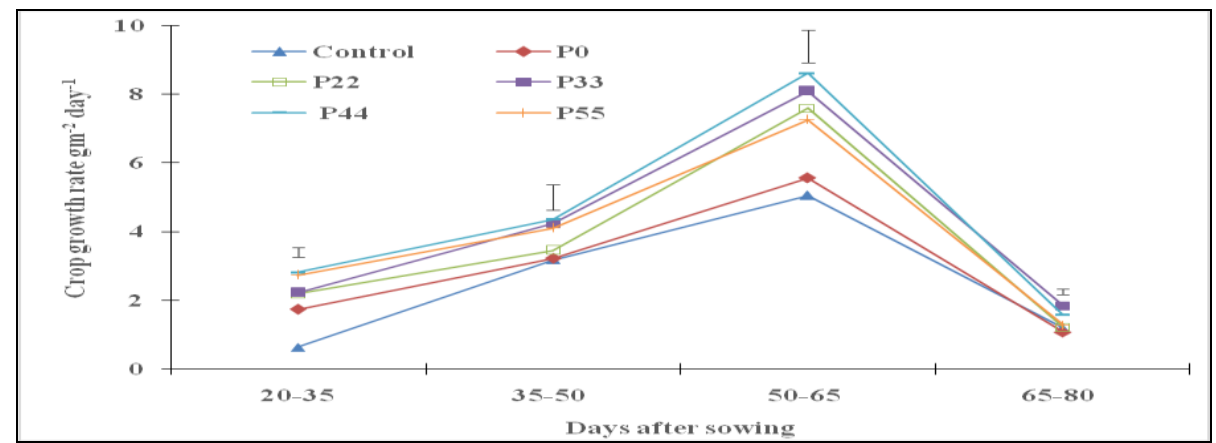

Fig. 11. Crop growth rate of French bean as influenced by phosphorus levels in Rabi season of 2010-11. 


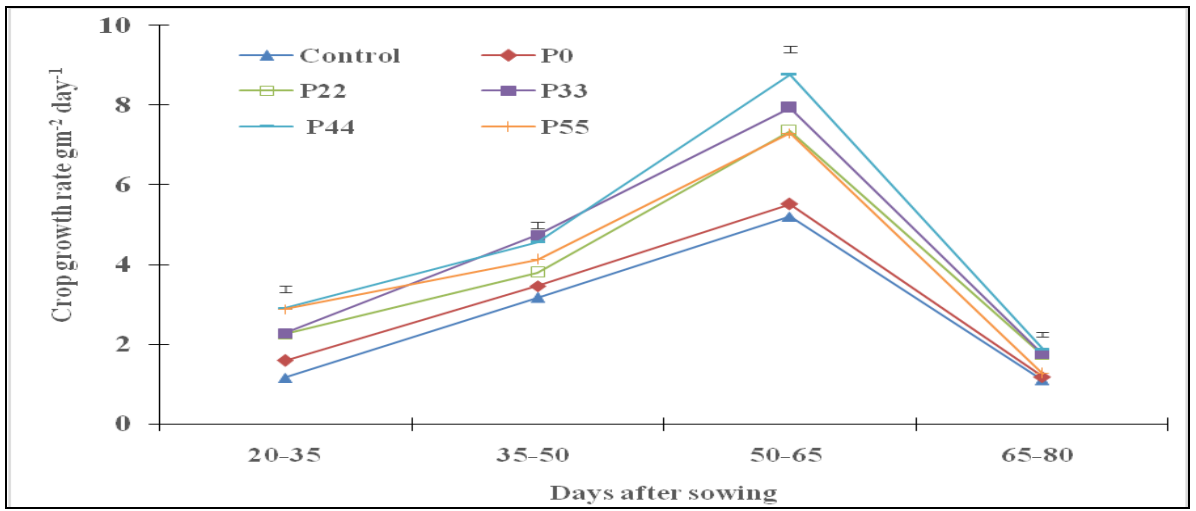

Fig. 12 Crop growth rate of French bean as influenced by phosphorus levels in Rabi season of 2011-12.

\section{Net assimilation rate}

The NAR generally showed a declining trend as the crop advanced in age of irrespective of $\mathrm{N}$ treatments (Fig. 13 and 14). The decrease in NAR after 50-65 DAS might be due to mutual shading of leaves, low content of leaf chlorophyll which caused lower leaf photosynthesis and there by lower CGR and lower NAR (Ferdous et al., 2004). Among the treatments, $150 \mathrm{~kg} \mathrm{~N}^{-1}$ maintained the highest NAR while no applied nitrogen and phosphorus $\left(\mathrm{N}_{0} \mathrm{P}_{0}\right)$ gave the lowest . At 50-65 DAS the NAR increased slightly, it might be due to higher CGR at this stage. This result was in agreement with Dhanjal et al. (2003) in French bean. Phosphorus levels also had significant effect on net assimilation rate in both the years ( Fig. 15 and 16). At 50-65 DAS, $44 \mathrm{~kg} \mathrm{P} \mathrm{ha}^{-1}$ gave the highest $\left(3.96 \mathrm{~g} \mathrm{~m}^{-2} \mathrm{~d}^{-1}\right.$ in 2010-11 and $3.84 \mathrm{~g} \mathrm{~m}^{-2} \mathrm{~d}^{-1}$ in 2011-12) net assimilation rate which was significantly higher than those of $\mathrm{P}_{0}$ (3.38 $\mathrm{g} \mathrm{m}^{-2} \mathrm{~d}^{-1}$ in 2010-11 and 3.24 $\mathrm{g} \mathrm{m}^{-2} \mathrm{~d}^{-1}$ in 2011-12).

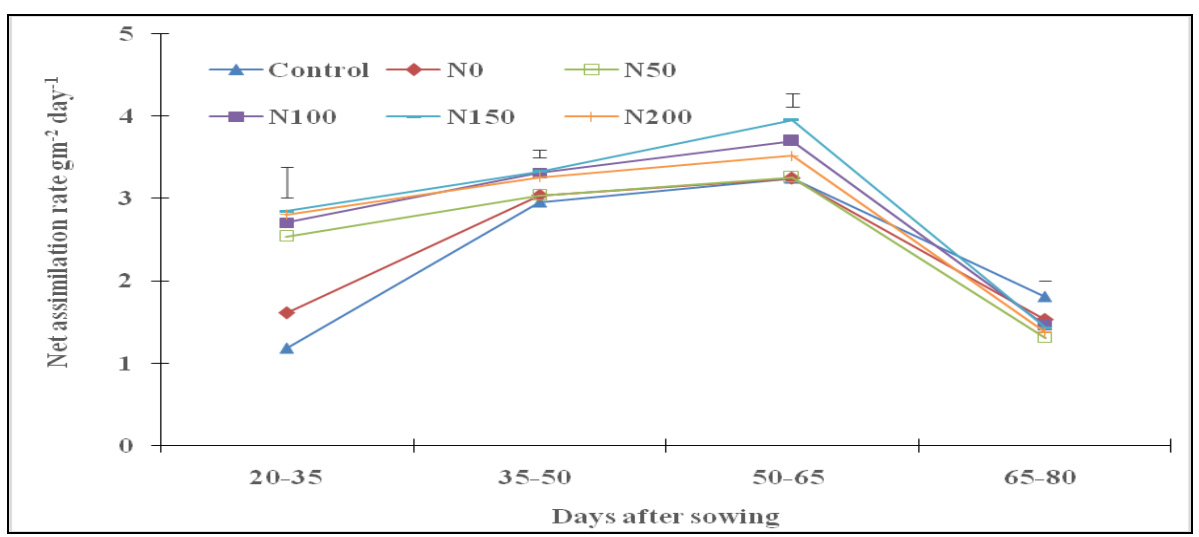

Fig. 13. Net assimilation rate of French bean as influenced by nitrogen levels in Rabi season of 2010-11. 


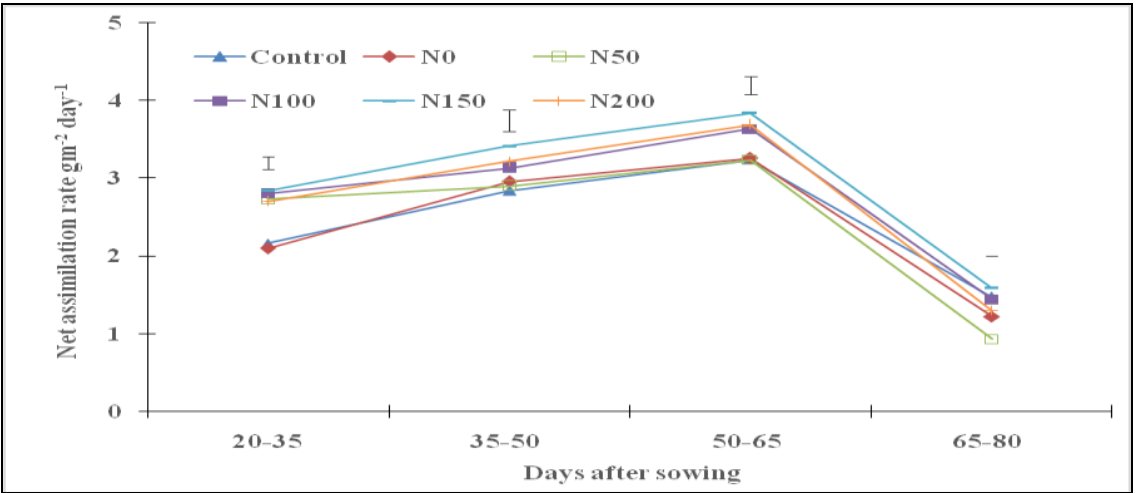

Fig. 14. Net assimilation rate of French bean as influenced by nitrogen levels in Rabi season of 2011-12.

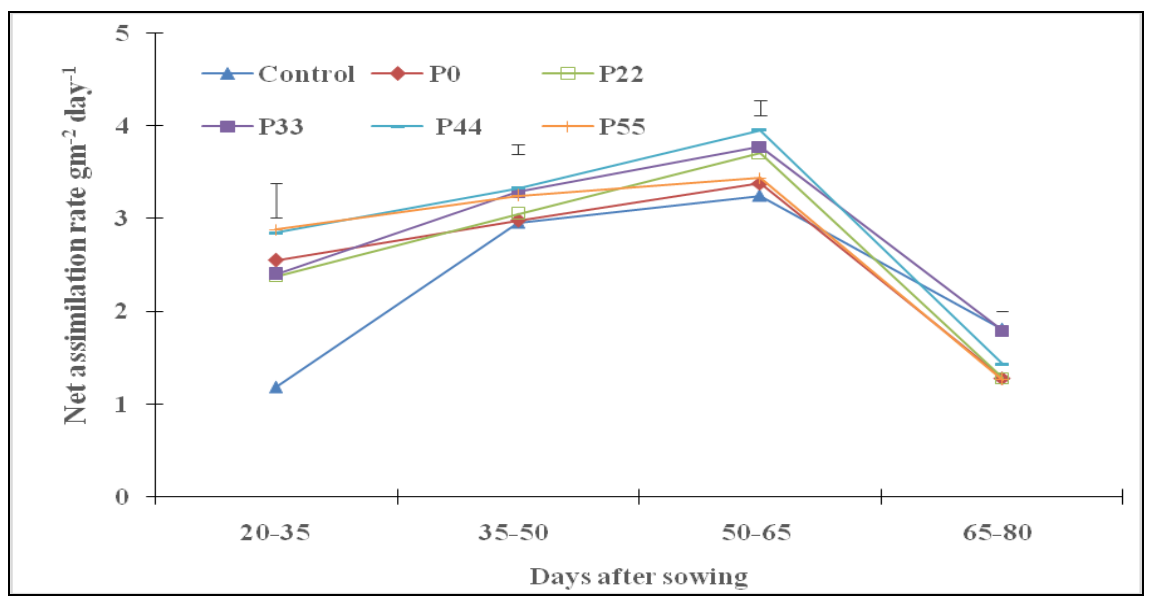

Fig. 15. Net assimilation rate of French bean as influenced by phosphorus levels in Rabi season of 2010-11.

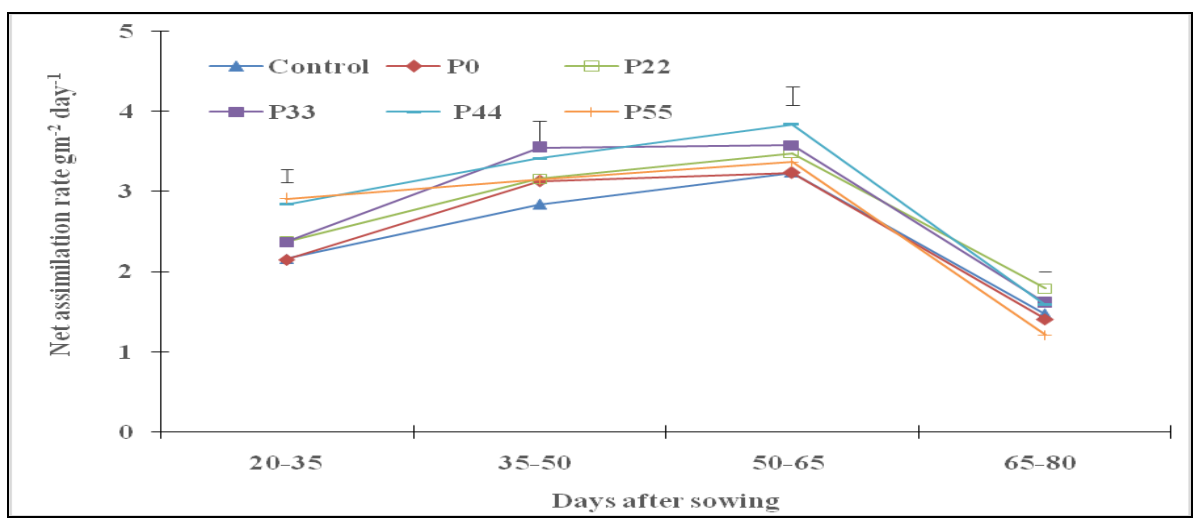

Fig. 16. Net assimilation rate of French bean as influenced by phosphorus levels in Rabi season of 2011-12. 


\section{Seed yield and yield contributing characters}

Seed yield and yield contributing characters of French bean were significantly influenced by different levels of nitrogen and phosphorus (Table 1). The number of flowers plant ${ }^{-1}$ and pods plant ${ }^{-1}$ significantly increased with the increasing levels of N. Plants treated with $200 \mathrm{~kg} \mathrm{~N} \mathrm{ha}^{-1}$ produced maximum number of flowers plant ${ }^{-1}$ (44.33 in 2010-11 and 50.00 in 2011-12) which was statistically similar to $150 \mathrm{~kg} \mathrm{~N} \mathrm{ha}^{-1}$. Nitrogen enhanced vegetative growth which might have caused for the longer time of flowering. Number of flowers plant ${ }^{-1}$ of French bean varied significantly due to phosphorus $(\mathrm{P})$ application. Plants grown in $\mathrm{P}$ treated plots recorded significantly higher number of flowers plant ${ }^{-1}$ over control. Plants treated with $150 \mathrm{~kg} \mathrm{~N}^{-1}$ produced maximum number of pods plant ${ }^{-1}$ (9.28 in 2010-11 and 9.62 in 2011-12) which was statistically similar to $100 \mathrm{~kg}$ $\mathrm{N}$. Number of pods plant ${ }^{-1}$ increased due to sufficient supply of $\mathrm{N}$ for better growth of plant which might have led to higher photosynthesis and the development of higher number of pod bearing branches (Kumar et al., 2004; Reddy et al., 2010). The number of pods plant ${ }^{-1}$ significantly decreased when nitrogen level increased from $150 \mathrm{~kg} \mathrm{ha}^{-1}$ to $200 \mathrm{~kg} \mathrm{Nha}^{-1}$. Significant variation in 100 - seed weight was observed among the $\mathrm{N}$ levels and it varied from $23.38 \mathrm{~g}$ and $18.74 \mathrm{~g}$ in 2010-11 while in 2011-12 these were between $23.14 \mathrm{~g}$ and 17.93 g. The maximum seed size (23.38 g in 2010-11 and $23.14 \mathrm{~g}$ in 2011-12) was observed in the plants grown with $150 \mathrm{~kg} \mathrm{~N}^{-1}$ which was statistically similar to $100 \mathrm{~kg} \mathrm{~N} \mathrm{ha}^{-1}$ and $200 \mathrm{~kg} \mathrm{~N} \mathrm{ha}^{-1}$. This parameter also significantly varied with $\mathrm{P}$ application in both the years (Table 1).The untreated control plants produced the smallest seeds (21.12g in 2010-11 and 20.87g in 2011-12).

Table 1. Number of flower plant ${ }^{-1}$, seed yield and yield components of French bean as affected by levels of nitrogen and phosphorus fertilizer in Rabi seasons of 2010-11 and 2011-12

\begin{tabular}{|c|c|c|c|c|c|c|c|c|c|}
\hline \multirow{2}{*}{$\begin{array}{c}\mathrm{N} \text { and } \mathrm{P} \\
\text { levels }\end{array}$} & \multirow{2}{*}{$\begin{array}{c}\text { Days reqd. } \\
\text { to } 1^{\text {st }} \\
\text { flowering } \\
\text { (DAS) }\end{array}$} & \multicolumn{2}{|c|}{$\begin{array}{l}\text { Flowers plant }{ }^{-1} \\
\text { (no.) }\end{array}$} & \multicolumn{2}{|c|}{ Pod plant $^{-1}$ (no.) } & \multicolumn{2}{|c|}{$\begin{array}{l}100-\text { seed } \\
\text { weight }(\mathrm{g})\end{array}$} & \multicolumn{2}{|c|}{ Seed yield $\left(\mathrm{kg} \mathrm{ha}^{-1}\right)$} \\
\hline & & $2010-11$ & 2011-12 & 2010-11 & 2011-12 & 2010-11 & $2011-12$ & $2010-11$ & $2011-12$ \\
\hline $\mathrm{N}_{0} \mathrm{P}_{0}$ & $37.67 \mathrm{c}$ & $24.67 \mathrm{e}$ & 11 & 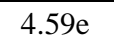 & 20 & $18.74 \mathrm{c}$ & 11 & 101 & $2 \mathrm{E}$ \\
\hline $\mathrm{N}_{0} \mathrm{P}_{44}$ & $39.00 \mathrm{bc}$ & $27.67 \mathrm{e}$ & $32.00 \mathrm{~d}-\mathrm{f}$ & 5. & $3 e$ & $19.17 \mathrm{c}$ & $\mathrm{cd}$ & $2 \mathrm{ef}$ & $8 \mathrm{e}$ \\
\hline $\mathrm{N}_{50} \mathrm{P}_{44}$ & $40.70 a-c$ & $34.17 \mathrm{~d}$ & $35.33 \mathrm{c}-\mathrm{e}$ & $6.33 c-e$ & $5.82 \mathrm{de}$ & $21.15 b$ & $20.51 b c$ & $956.79 \mathrm{de}$ & $981.98 \mathrm{~d}$ \\
\hline $\mathrm{N}_{100} \mathrm{P}_{44}$ & $42.00 \mathrm{a}-\mathrm{c}$ & $38.17 \mathrm{bc}$ & $41.00 \mathrm{bc}$ & $8.08 \mathrm{a}-\mathrm{c}$ & $7.87 \mathrm{a}-\mathrm{c}$ & $23.06 \mathrm{a}$ & 22.73ab & $1375.12 \mathrm{a}-\mathrm{c}$ & $1413.15 \mathrm{a}-\mathrm{c}$ \\
\hline $\mathrm{N}_{150} \mathrm{P}_{44}$ & $42.43 \mathrm{a}-\mathrm{c}$ & 41.3 & 45. & & & $23.38 \mathrm{a}$ & $23.14 \mathrm{a}$ & $3 a$ & $33 a$ \\
\hline $\mathrm{N}_{200} \mathrm{P}_{44}$ & $44.83 \mathrm{a}$ & $44.33 \mathrm{a}$ & $50.00 \mathrm{a}$ & $9.07 \mathrm{a}$ & $9.23 \mathrm{ab}$ & $21.83 \mathrm{ab}$ & $22.13 a b$ & 145 & $1479.63 \mathrm{ab}$ \\
\hline $\mathrm{N}_{150} \mathrm{P}_{0}$ & $44.67 \mathrm{a}$ & $25.67 \mathrm{e}$ & $30.43 \mathrm{ef}$ & $6.68 b-d$ & $7.06 \mathrm{~cd}$ & $21.12 b$ & $20.87 a-c$ & $1158.27 \mathrm{~cd}$ & $1206.36 \mathrm{c}$ \\
\hline $\mathrm{N}_{150} \mathrm{P}_{22}$ & $41.73 a-c$ & $35.67 \mathrm{~cd}$ & $38.40 \mathrm{~b}-\mathrm{d}$ & $7.53 a-c$ & & 22.4 & $a b$ & $1259.75 b c$ & $38 \mathrm{bc}$ \\
\hline $\mathrm{N}_{150} \mathrm{P}_{33}$ & $43.07 \mathrm{ab}$ & $38.33 b c$ & $41.33 b c$ & $8.50 \mathrm{ab}$ & $8.71 \mathrm{a}-\mathrm{c}$ & $22.76 \mathrm{a}$ & $22.20 \mathrm{ab}$ & $1495.00 \mathrm{ab}$ & $1536.90 \mathrm{ab}$ \\
\hline $\mathrm{N}_{150} \mathrm{P}_{55}$ & $43.00 \mathrm{ab}$ & $41.00 \mathrm{ab}$ & $43.87 \mathrm{ab}$ & $8.35 \mathrm{ab}$ & $8.62 \mathrm{a}-\mathrm{c}$ & $22.16 \mathrm{ab}$ & 21.83ab & $1420.00 \mathrm{a}-\mathrm{c}$ & $1460.00 \mathrm{ab}$ \\
\hline $\mathrm{CV}(\%)$ & 4.49 & 4.65 & 6.83 & $10 . .13$ & 9.31 & 2.89 & 4.51 & 8.88 & 7.25 \\
\hline
\end{tabular}

$\mathrm{CV}=\mathrm{Co}$ efficient of variation.

In a column, figures having common letter(s) do not differ significantly at $1 \%$ level by DMRT. 


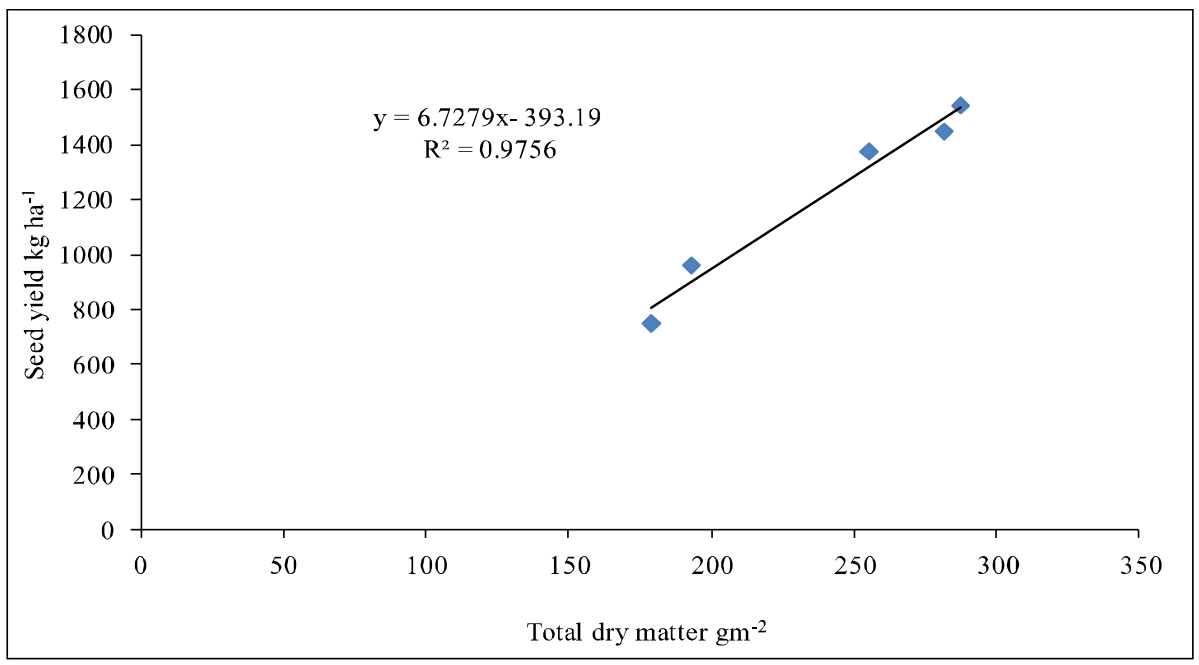

Fig. 5a. Functional relationship between total dry matter and seed yield of French bean as affected by nitrogen level during Rabiseason of 2010-11.

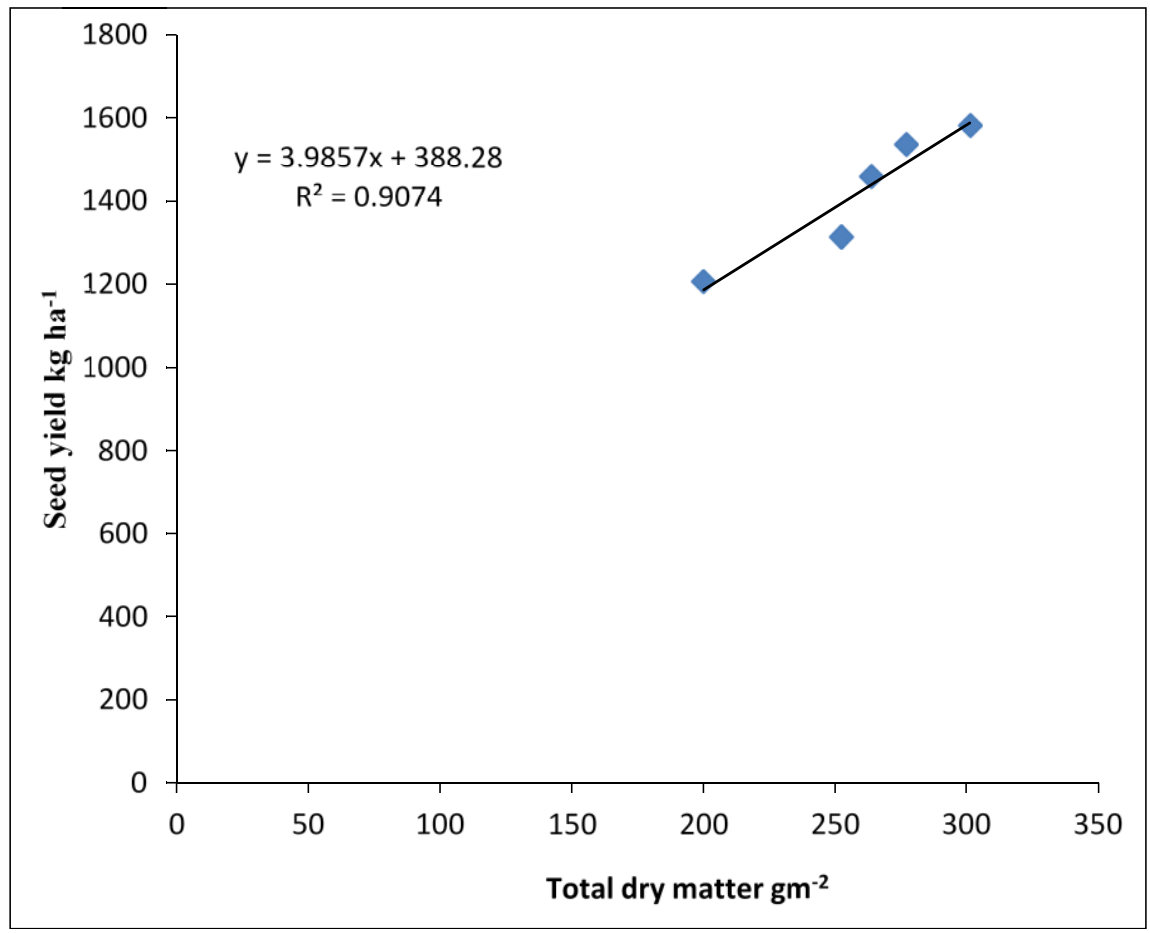

Fig.6a. Relationship between total dry matter and seed yield of French bean as affeted by nitrogen level during Rabi season of 2011-12. 


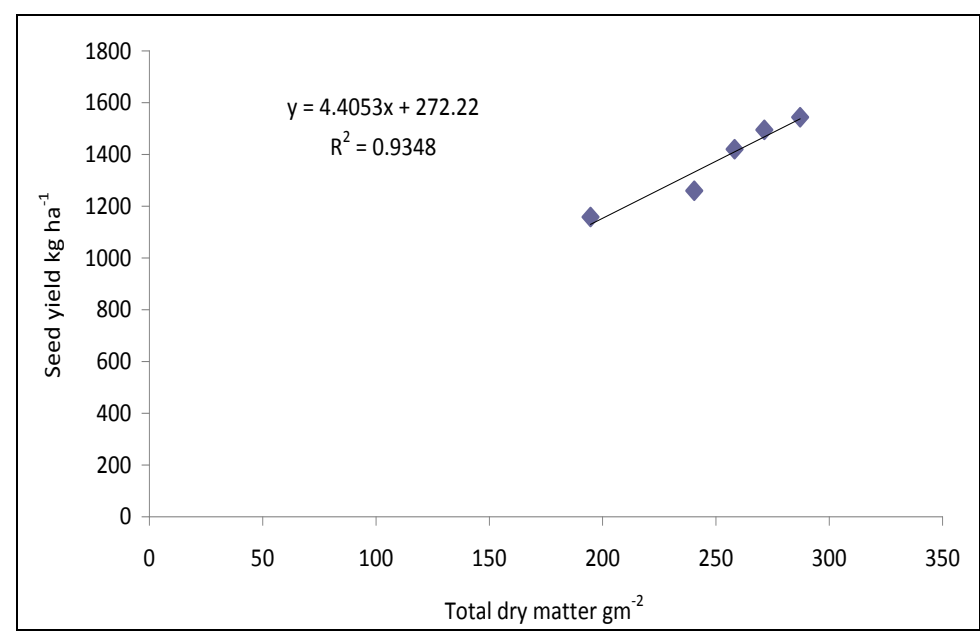

Fig.7a. Functional relationship between total dry matter and seed yield of French bean as affected by phosohorus level during Rabi season of 2010-11.

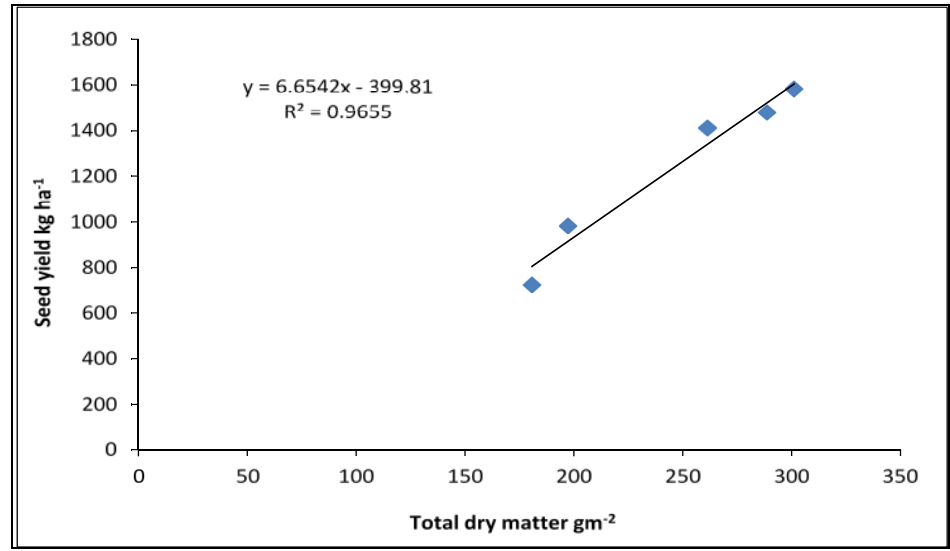

Fig 8a. Relationship between total dry matter and seed yield of French bean as affected by phosphorus level during Rabi season of 2011-12.

The highest yield over the years (1543.33 and $\left.1583.33 \mathrm{~kg} \mathrm{ha}^{-1}\right)$ was recorded with $150 \mathrm{~kg} \mathrm{~N} \mathrm{ha}^{-1}$ due to higher values for yield attributes (pods plant ${ }^{-1}$ and 100 -seed wt.) compared to $0 \mathrm{~kg} \mathrm{~N} /$ ha. Although $200,100 \mathrm{~kg} \mathrm{~N} \mathrm{ha}^{-1}, 33$ and $55 \mathrm{~kg} \mathrm{P} \mathrm{ha}^{-1}$ treatments were identical to $\mathrm{N}_{150} \mathrm{P}_{44} \mathrm{~kg} \mathrm{ha}^{-1}$. The increase in yield might be due to increased availability of nitrogen, causing accelerated photosynthetic rate leading to more production of carbohydrates and improvement in growth and yield attributes. These results agree with the findings of ( Reddy et al., 2010) in French bean. Regression analysis was done to quantify the relationship between total dry matter and seed yield of French bean under different nitrogen and phosphorus level. There was positive linear relationship between total dry matter and seed yield (Fig. 5a; 6a; 7a; 8a). The functional relationship revealed that 98, 
91, 94 and $97 \%$ of the variation in seed yield could be explained from the variation in total dry matter in both the years. From the regression analysis it is observed that seed yield was related with the $\mathrm{N}$ and $\mathrm{P}$ levels following a quadratic relationship (Fig. 19 and 20) averaged over years. From the quadratic regression, $\mathrm{Y}=-0.026 \mathrm{~N}^{2}+9.33 \mathrm{~N}+684.7$, it is estimated that $178 \mathrm{~kg} \mathrm{~N} \mathrm{ha}^{-1}$ is optimum dose for getting maximum seed yield of French bean. Srinivas and Naik (1990) also reported optimum dose $\left(160 \mathrm{~kg} \mathrm{ha}^{-1}\right)$ in their field trial. Similar observation was reported in French bean by (Kaisar et al., 2007). The response of seed yield to phosphorus was quadratic in nature and from the regression equation, $\mathrm{Y}=-0.141 \mathrm{P}^{2}+13.81 \mathrm{P}+1356$, the estimated optimum levels for getting maximum seed yield was $48.97 \mathrm{~kg} \mathrm{P} \mathrm{ha}^{-1}$. Srinivas and Naik (1990) reported optimum dose of phosphorus $60 \mathrm{~kg} \mathrm{P} \mathrm{ha}^{-1}$.

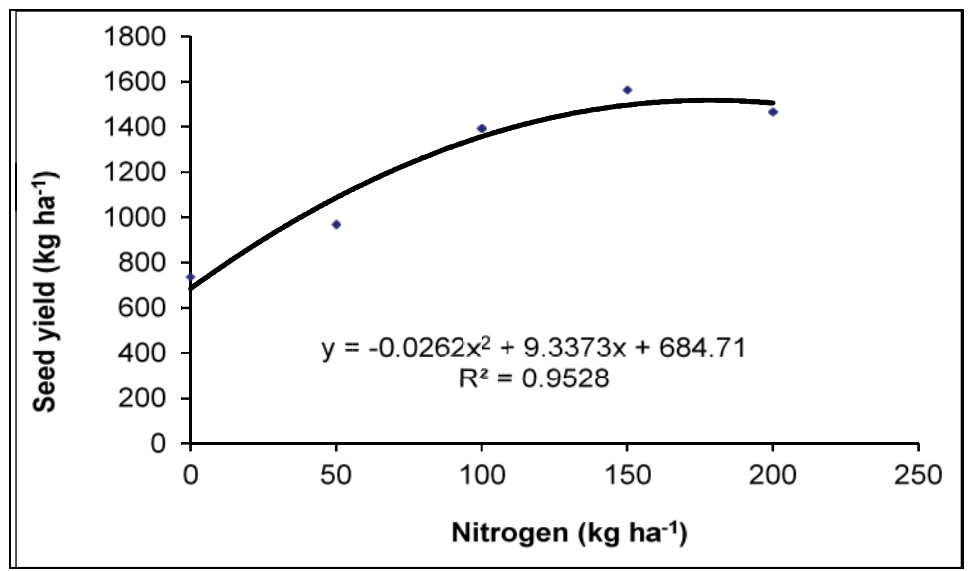

Fig.17. Seed yield of French bean as affected by level of nitrogen fertilizers averaged over years.

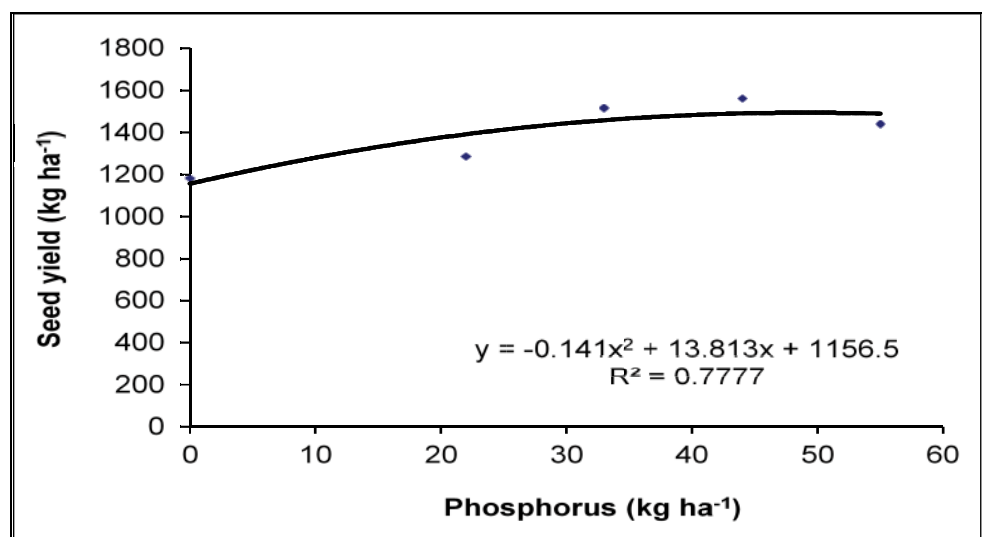

Fig. 18. Seed yield of French bean as affected by levels of phosphorus fertilizers averaged over years. 


\section{Conclusion}

Two years result revealed that the application of $\mathrm{N}$ and $\mathrm{P}$ fertilizer up to150 and $44 \mathrm{~kg} \mathrm{ha}^{-1}$ exerted positive effects on French bean in terms of growth and seed yield in Joydebpur area.

\section{References}

BARI (Bangladesh Agricultural Research Institute). 2001. Basat Barite Sabji Utpadan. In Bangla. Bangladesh Agricultural Research Institute, Gazipur, Bangladesh. p. 239.

Dhanjal, R., O. Prakash and I.P.S. Ahlawat. 2003. Physiological variation in French bean (Phaseolus vulgaris) cultivars as affected by plant density and nitrogen. Indian J. Plant Physiol. 8: 34-37.

Ferdous, A.K.M., Q.A. Khaliq, M.M. Hoque, A.J.M. Sirajul Karim and M.S.A. Bhuyian. 2004. Effect of nitrogen fertilizer on growth, nitrogen and phosphorus uptake and yield in edible podded pea. Bangladesh Agron. J. 10 (1 \& 2) : 133-140.

Gardner, F.P., R.B. Pearce and R..L. Mitchell.1985. Growth and development. In: Physiology of Crop Plants. Iowa State Univ. Press, Amer. USA. Pp. 187-208.

Hoque, M.S. 1993. Bradyrhizobium technology: a promising substitute for chemical nitrogen fertilizer in Bangladesh Agriculture. Plant and Soil. 155/156:337-340.

Kaisar, M.O., S. Zaman, A.K.M.S. Hoque, S.M.L. Rahman and M.M. Zaman 2007. Effect of nitrogen and phosphorus on growth, yield and profitability of French bean. Bangadesh J. Pro. Sci. \& Tech. 5(2): 373-376.

Kumar, M., K.K. Sinha and R.P. Roy Sharma. 2004. Effect of organic manure, NPK and boron application on the productivity of French bean in sandy loam soil of north Bihar. Indian J. Pulses Res. 17 : 42-44.

Machler, F., A. Oberson, A. Grub and J. Nosberger. 1988. Regulation of photosynthesis in nitrogen deficient wheat seedlings. Plant Physiol. 87:46-49.

Mozumder, S.N., M. Moniruzzaman, M.R. Islam and S.N. Alam 2003. Effect of planting time and spacing on the yield performance of bush bean (Phaseolus vulgaris L.) in the eastern hilly area of Bangladesh. Legume Res. 26(4): 242- 247.

Reddy, M., Malla. Padmaja, B. Reddy and R. Ram 2010.Response of French bean to irrigation schedules and nitrogen levels in Talangana region of Andhra Pradesh. $J$. Food legumes. 23(1): 38-40.

Siddiqui, Md Noor- E- Alam. 2010.Response of bush bean to applied nitrogen and phosphorus. Ph.D. Thesis, Department of Agronomy, Bangabandhu Sheikh Mujibur Rahman Agricultural University, Salna, Gazipur.

Srinivas, K. and L.B. Naik 1990: Growth, yield and nitrogen uptake in vegetable French bean (Phaseolus vulgaris L.) as influenced by nitrogen and phosphorus fertilization. Haryana J. Hort. Sci. 19 (1-2): 160-167.

Tanaka, A.,J. Yamaguchi, S.Miura and H. Tamaru.1984. Comparison of fertilizer nitrogen efficiency among field crops. Soil Sci.Plant Nutr.30 (2): 199-208.

Wolfe, D.W., D.W. Henderson, T.C. Hsiao and A. Alvino. 1988.Interactive water and nitrogen effects of senescence of maize II. Photosynthesis and longevity of individual leaves. Agron J. 80: 865-870. 